\title{
Turkey`s Harmless Tango Between East and West
}

Selma Mujanović*

\begin{abstract}
Turkey got actively involved in world politics and international relations after AKP came to power in early 2000s. Turkey`s foreign policy since AKP came to power, has the theoretical basis in Davutoglu`s Strategic Depth. New doctrines rely on historical right inherited from the Ottoman Empire, which contributed towards Turkish pro-active and multi-dimensional foreign policy. Without forgetting traditional Western allies, Turkey has established itself as a regional power in the Balkans, Middle East and Central Asia with significant success. This paper attempts to analyze how Turkey has been playing a harmless tango between its traditional allies in the West and regions in the near abroad which had made Turkey a global player in the international relations. Then, it is important to analyze Turkey's transformation and its approved role by the Western powers as a strong Islamic country with secular governance in the Middle East and Central Asia.
\end{abstract}

Keywords: Turkish Foreign Policy; Neo-Ottomanism; AKP Party; EU; the Balkans; the Middle East; Central Asia

*Selma Mujanović; Doctoral Candidate International University of Sarajevo; e-mail: selma.sulejmanovic@gmail.com 


\section{Traditional Turkish Foreign Policy}

Traditional Turkish foreign policy dates back to the period when Ottoman Empire was close to its demise in the beginning of the twentieth century. During this critical time Ataturk emerged as a leader who saved Turkish territorial integrity from the greedy Western powers who aimed at taking different parts of Turkey. During the Berlin Congress (1878) the Ottoman Empire was marked as a Sick Man of Europe. Therefore, the partitioning of the Ottoman Empire was a political agreement that took place after the World War I. Italy was given southwestern Anatolia, Greece was given Ionia and Smyrna(Izmir), Aegean region and Rhodes Island were given to Britain together with the Cyprus, Straits and Istanbul were under International mandate, Russia was given Armenia, Georgia and Azerbaijan. Nonetheless, after the end of the World War I Germany, Austria and Ottoman Empire were severely defeated by the Allied powers that quickly moved forward to partition Ottoman territories. Then, Britain conquered Palestine, Syria, Iraq and southeastern parts of Turkey. Italy was conceded southwestern Anatolia. Greece was allowed to occupy of Turkish provinces of Thrace, Izmir and Aegean Islands Turkish straits were put under joint influence of allied powers due to its international importance (Turk Istiklal Harbi, 1992).

At that time Turkey`s Arab neighbors aligned with the Western Powers against Turkey. This was a shocking "knife in the back" from the Arab brothers, thus Kemalist regime after Turkey gained independence, always approached Arab neighbors with a great suspicion. In addition to this newly established Turkish elite, united under the rule of Ataturk perceived the Ottoman expansion in the Balkans and Arab countries as a disastrous policy that nearly resulted in demise of the Turkish Republic. Thus, the main aim of newly formed Turkish elite was to distance Turkey from its Ottoman past. The new elite did not recognize Turkish past and they introduced certain measures as to make people forget the legacy of the great Ottoman Empire. They were basically ashamed of their past and rejected entirely past Ottoman legacy. Nonetheless, the common people and grassroots of the Turkish elites did not forget their past and they continued valuing the Ottoman legacy as other great world empires.

Almost all of the works on traditional Turkish Foreign policy emphasize the real-politics of the Turkey`s decision-makers and its foreign policy from the early years of the Turkish Republic. Real-politics in Turkey lead to tight security structure and prominent role of military in Turkish 
political affairs (Karaosmanoglu, 2000). As a result of internal political developments Turkey joined NATO in 1952 in the wake of communist expansion in order to protect the Western world from the communist threat. This move defined the Turkish foreign policy for the whole period of Cold War that came to close in 1991 (Kuniholm, 1980, p. 325). In the vacuum that followed after the fall of Iron Curtain and the end of Cold War Turkey continued with its Western orientation and NATO's membership.

\section{Turkish New Foreign Policy}

The emergence of Turkish New Foreign Policy needs to be looked at as a fusion of the international, regional and national actors. The international actors change after the end of the Cold War led to a systematic change in the Turkey`s near political environment. In fact, the systematic change was to a great extant responsible for the shift in Turkish foreign policy and its role in the region. In order to fill the vacuum that emerged in the Central Asia, Turkic republics so closed to Turkey, the United States and its European allies presented Turkey as a country model that combines moderate Islam with secularism, for these newly independent countries of Central Asia (Bal, 2000, p. 232). Thus, Turkey felt encouraged by the United States to approach Central Asian states and to promote moderate Islam. Actually, the US president George H. W. Bush proposed that Turkey, with its tradition of Sufi-influenced Islam and secular regime could serve as a perfect model for other Islamic countries in the region. The idea that came from the United States was called as "Turkish Model." In this regards, Turkey felt encouraged by the United States to reach out to the governments of Islamic countries and to support regimes in these countries. On the other hand, most recently the US administration under Obama has tried to find the other approach to Islamic regimes in the Middle East by redefining Islam and its practices by subordinating it to the American interests in the region. For this purpose the new generation of so called "moderate Islamists" among the Arabs were used (Rabasa, et. al., 2007).

At the regional level Turkish foreign policy was affected by the vacuum that was left by the 1991 Gulf War and 2003 Iraqi War. In addition, the significant impact on Turkish foreign policy had the deterioration of Kurdish problem and, as well as, the dynamic change in Arab-Israeli relations. The deterioration in Arab-Israeli relations provided Turkey with the opportunity to become mediator between Arabs and Israelis. 
Turkey has managed to establish itself as successful mediator in the regional conflicts up until the Operation Cast in Gaza during the winter of 2008-2009. Effective Turkish mediation in the region was accompanied by the United States waning influence as well as stalled negotiations between Turkey and the EU regarding Turkey`s EU membership.

In order to understand the change in domestic policy of Turkey that took place under the AKP rule it is important to understand the domestic political scene that existed in Turkey after the end of the Cold War. Under the 1981 Turkey`s constitution, Turkey`s National Security Council (Milli Guvenlik Kurulu) was established for policy coordination between democratically elected legislative, military and president of the republic. However, Turkey`s coalition governments were highly unstable and many corruption scandals and it comes as no surprise that general public saw military as sole guardian of their Republic (Jenkins, 2001). Up to 2007, the constitutional court of Turkey and the president of the Republic checked the power of parliamentary majority. However, in 2007 when ex AKP party member, Abdullah Gul was elected as a president, a gate for curtailing the power of military and its interference in foreign and domestic policy of Turkey was opened. Thus, under AKP rule the constitutional and institutional changes and reforms have taken place so that power of military came under civic rule as in other parliamentary democracies (Cook, 2010).

\section{The Turkey`s Neo-Ottomanist Vision and new Turkish Political Elite}

Kemalism is still present in Turkey nonetheless; it is definitely not ascending in popularity. New political elites, that had role models in Turgut Ozal (1983-1989) and Necmettin Erbakan (1996-1997), had emerged and introduced new vision of foreign policy and governance. Besides, public interest in the foreign policy and policy in general, has risen to a great extant. The most important contribution to the AKP's new foreign policy orientation was the work titled as Strategic Depth (Strejik Derinlik) written by Ahmet Davutoglu in 2001, which turned out to be a foreign policy guideline of the AKP. The origins of Strategic Depth and key ideas are greatly based on the multidimensional foreign policy of Necmetin Erbakan and Turgut Ozal`s Neo-Ottomanism. The Strategic Depth is based upon historical and geographical depth. Geographical depth of Turkish republic lies in the fact that Turkey is legal successor of the Ottoman Empire (Murinson, 2006, p. 947). 
After the end of Cold War, Turkey became a country which was surrounded by the two major zones of instability. First zone was Balkans and the second was the Middle East. Both zones were unstable and consequently they were involved in various wars. In addition, in the 1990s Turkey on the brick of war Armenia, Greece and Syria. Then, Turkey was regularly involved in military interventions in the North Iraq. Turkish relations with Iran deteriorated due to the Kurdish conflict and ever present political Islam. Therefore, Turkey's overall approach to its neighbors in 1990s was characterized by the mistrust, confrontation and threats. In contrast to this kind of foreign policy, new foreign policy of Turkey took place in the 2000s was characterized by rapprochement with Syria, Iraq, Iran, Armenia and Russia. Shortly Turkish foreign policy in 2000s was characterized by "zero problems" policy with its neighbors which first and foremost aimed at improvement of bilateral relations as well as regional cooperation especially in the ex-Soviet republics and the Balkan states. As the 2000s progressed this cooperation was extended to the Middle East and the North Africa (Evin, 2010).

The architect of new Turkish foreign policy Davutoglu in his work emphasized the fact that Turkey is unique due to two reasons. First is its location in geographical areas that are of great importance mainly thinking about straits of Bosporus and Dardanelle. Second reason is historical and it relates to the fact the Turkey is legitimate heir of the Ottoman Empire (Davutoglu, 2001). Traditional measures of Turkey`s power overlook its cultural heritage as an advantage, which was different with Davutoglu's vision of foreign policy. Davutoglu emphasizes the importance of Turkey's cultural heritage as an asset in approaching the Balkans, Middle East and Central Asia. Turkey is a legal heir to the Ottoman Empire that once united the Muslim world and therefore Turkey as a trans-regional power can once more unite and lead the Muslim world (Davutoglu, 2001). Accordingly, Turkey is not just an ordinary nationstate that emerged as a result of the will of the great powers after the World War I rather in Davutoglu's words “Turkey is a regional power in its own right, having strong tradition of statehood and broad strategic outreach. Thus, it has no chance of being peripheral since it is not a sideline country of the EU, NATO or Asia" (Mourinson, 2006, p. 945964). He continues by arguing that "Turkey is centrally positioned international player, a country with a close land basin, the epicenter of the Balkans, the Middle East and the Caucasus, the center of Eurasia in 
general and it is in the middle of Rimland belt cutting across the Mediterranean to the Pacific" (Mourinson, 2006, p. 945-964). One can easily notice from Davutoglu's statements that new foreign policy reflects the newly-acquired self-respect and self-confidence on the part of newly elected Turkish leadership under AKP rule. The leadership that supported the more proactive approach to the foreign policy particularly in the area of so-called "Ottoman geopolitical space. " Furthermore AKP leadership was more than a critical of the myopic Turkey's Cold War foreign policy and neglecting of the Ottoman cultural and historical heritage.

Central issue in the AKP's revival of Ottoman legacies has been the expanding of its economic interests. The central point to this argument involves the emergence of new classes of businessmen from Anatolia who were pious and devout Muslims. This class of businessmen started to compete with traditional Aegean businesses. Thus, Anatolian businessmen were the ones that forced AKP government to focus on Middle East whose markets were expanding rapidly. Having in mind this it is not hard for many to imagine why Turkey had changed this foreign policy toward Iran, Iraq or Syria if it has not been for wealthy Anatolian business elite. Their economic interests have played a great role in the context of new Turkish foreign policy orientation (Evin, et. al., 2011). Then, since 2000 Turkey has sought to counterbalance its dependence on the West by courting different alliances to maintain the balance of power in the region. In Davutoglu's opinion Turkey should not be dependent upon only one actor and should all the time seek to balance it's relations and alliances so that it can maintain optimal independence and leverage on global and regional stage (Davutoglu, 1994).

\section{Turkish Foreign Policy toward EU}

AKP was more than eager to approach Turkey to the EU because according to many analysts this party was presupposed to be an Islamist party that doesn't prefer any alliance with the West and EU. Nonetheless, having those negative views in mind AKP tried its best to open as many chapters within EU accession framework. In the end due to those reforms Turkish military had an important role in protecting Turkey`s Kemalist legacy that gave upon the idea of Turkey`s EU accession since the reforms that were supposed to take place in the case that Turkey joins EU were supposed to put military under civilian rule. 
Turkey submitted its application to join European Economic Community, that latter on became to be known as European Union, dates back to 1959 which resulted in associate membership not before 1963. Full membership has been the final goal. Nonetheless, for Turkey various problems emerged such as Cyprus conflict together with internal political turmoil, which made Turkey through all 1970 and mostly 1980s away from the European Union. In 1987 Turkish official membership application was rejected by the EU. However, rejection did not prevent Turkey`s involvement with the EU on various other issues such as customs. Turkey and the EU signed customs Union which became effective as of $1^{\text {st }}$ of January 1996.

EU confirmed Turkey`s status as a candidate country during Helsinki Summit in 1999. Nonetheless, accession talks did not start immediately since Turkey needed to make significant reform in the human rights. After the Helsinki Summit Turkey made very important and daring reforms and passed them through parliament with an aim to harmonize Turkey with EU standards. Formally, Turkey started its EU accession talks in October 2005. Nonetheless, in December 2006 EU decided to suspend part of the negotiations with Turkey by freezing eight chapters because Turkey did not recognize the Republic of Cyprus. Turkey also did not grant access of Cypriot vessels and planes to Turkish harbors and airports. Since then the negotiations between Turkey and EU are still taking place but they are very slow (Christensen, 2009, p. 10).

In 2004, as a result of the efforts of the ruling AKP Turkey became the EU candidate. Nonetheless, the EU became great disappointment for Turkey because of devaluing of Turkey as potential member-country. Disappointment with EU contributed towards Turkish search for prominent role in the Muslim world. No one was more eager and ready to approach Turkey to the EU then the newly elected AKP government which were described, as soon as they assumed the power, as an Islamic party. AKP was looked at by Kemalist elite and Turkish military as a party whose government would distance Turkey from the West and its values that Kemalist Turkey was trying so hard over the years to acquire. Nonetheless, AKP as soon as they formed government surprised everyone with the eagerness to make Turkey EU member as soon as possible. AKP new that they would be blamed if Turkey don't progress on its way to EU. Thus, AKP pushed for reforms in judiciary and lately in military as well all in order to complete requirement of the EU. 
Nonetheless, the more Turkey adopted EU reforms the less stimulus came from the EU. Some countries of the EU even started to question whether Turkey was in Europe at all. Nicolas Sarkozy, President of the Republic of France and German Chancellor Angela Markel went that far to propose Turkey some kind of partnership which was immediately rejected by the Turkish government. Turks, whose national sentiments are very high and whose national pride is at the first place beginning to think that EU, with the proposal of something less than EU membership has humiliated Turkish Republic, have started to look at the Turkey`s accession into EU with a great suspicion. In 2004, $73 \%$ of Turks were in favor of Turkey`s EU membership, nonetheless, in 2006 that number dropped to 54\%. In 2007 this number fell to only 40\%. This coincided with the economic stability and progress which started to take place as the AKP came to power. It is widely known that confidence of one country increases as its economic strength increases.

\section{Turkish Foreign Policy toward Middle East, Central Asia and Balkans}

Under the AKP government Turkish influence has been growing steadily in the Middle East, Central Asia and the Balkans. Turkish secular elite has strong cultural ties with the West and they viewed Iran and Arab countries as hostile neighbors, never forgetting Arab knife in the back from the mid nineteenth century until the establishment of the Republic of Turkey in 1922. Nonetheless shift in Turkish foreign policy has been evident since AKP came to power. During AKP years Turkey has been trying to develop an intensive relation with all countries especially with its neighboring countries. Nonetheless, its relations are based upon rational calculations not on ideological accounts (Davutoglu, 2008). Turkish foreign policy vision perceived international relations as a whole with no borders. Turkey became engaged from Chile to Indonesia and from Africa to Central Asia, from EU to OIC (Davutoglu, 2008). In the party program of AKP it is expressed that the end of Cold War and global restructuring has brought the change in environment and has developed a several alternatives in the area of foreign policy area (AKP Party Program, 2001). Pro-active rhythmic diplomacy refers to "a sustained pro-activism in the field of diplomacy, trying to achieve a more active role in international organizations and opening up to new areas where Turkish contacts are have been limited in the past" (Davutoglu, 2008, p. 83). Parallel to Davutoglu's vision AKP party program suggests a "forward looking, proactive, innovative, and ultimately multifaceted 
foreign policy“ (AKP Party Program, 2001) which aims at being more initiative regarding the crisis in the neighboring countries with more concrete contribution to permanent solutions.

The re-emergence of new Anatolian business elite contributed towards Turkish more proactive foreign policy toward the Middle East. Turkey has been active in promoting diplomatic contacts between Syria and Israel and it has mediated the talks between the same parties during the Israeli occupation of the Golan Heights (Onis, Yilmaz, 2009, p. 19). Syrian President introduced a peace treaty in return to Israel's evacuation of Heights in April 2008. Nonetheless, what followed was Gaza attacks and new government under Netanyahu declared that "Israel would not code the Golan Heights for the sake of peace with Syria." However, the main emphasis in the Turkish foreign policy towards the Middle East was the Palestinian question. Turkish policy makers evaluate the Palestinian issue as their area of responsibility and at the same time they see a chance to claim a constructive role in the Middle Eastern peace building process. In this regard, Turkey tries to deter Israeli aggression against the Palestinians and at the same time to reduce as much as possible terrorist attacks on innocent Israeli civilians. Nonetheless, Turkish-Israeli relations reached the lowest point on 31 of May 2010 when six Turkish ships, called Gaza Freedom flotilla, entered international waters in the Mediterranean Sea and were blocked by Israeli ships. One of the six ships called Mavi Marmara showed resistance to Israeli soldiers who entered their ships and 9 people were killed by the Israeli soldiers. This caused deterioration in Turkish-Israeli relations and at the Israeli Ambassador to Ankara was expelled from Turkish capital. Relations were not reestablished up until 22 march 2013 when Israeli Prime Minister called his Turkish colleague Recep Tayyip Erdogan and apologized for Mavi Marmara event.

Moreover it is very important to look at the Turkey's involvement in the various Islamic organizations that unite Islamic countries. Turkey has developed institutional and strategic cooperation with the Arab League and Gulf Cooperation Council. It plays an active role in the Islam Conference Organization and has an observer status in the Organization of African Unity. Nonetheless, Turkey has been disappointed by the EU and its policies. According to Turan (2010):

The security shield provided by NATO for example, enables Turkey to deal more confidently with Russia as 
an economic partner. Turkey continues to rely on the United States as a major source of arms procurement. The fact that around half of Turkey's exports go to EUmember countries and that Germany is Turkey's largest trading partner generate significant interest in retaining a good working relationship with the European Union. Turkey's soft power is considerably enhanced in the Middle East, the Caucasus, and Central Asia by the fact that it has a strong Western connection. Turkey's relations with Iran have to be balanced with those with Saudi Arabia and the Gulf States that are allied with the United States. Turkey's strong challenge of Israeli policies in Palestine has reduced the appeal of Iran in the region, while its vastly improved relationship with Syria has reduced Iranian influence there as well and has rendered Turkey more interested in a negotiated solution with Israel. These developments are all in harmony with the American and EU policies in the region. Turkey shares an interest with the United States and the EU in the development and survival of a united, independent, and stable Iraq. Similarly, both Turkey and its Western partners share an interest containing the spread of radical Islamic movements and terror under the guise of religion.

Thus, when evaluating the Turkey`s foreign policy toward the Middle East one should bear in mind that real-politics in is not marginalized to the extent that Turkey would compromise its relations with the West visà-vis its relations with the Middle Eastern countries. Central Asia is strategically important region for ensuring the security and stability of the Euro-Atlantic region and its energy resources are vital for global energy (Turkey's Relations with Central Asian Republics, n.d.). Turkey was one of the first countries that recognized the independence of the Central Asian republics once they proclaimed their independence from the Soviet Union.

Due to strong cultural ties between Turkey and Central Asian republics Turkey has sought to increase the engagement with the Central Asian republics on the broad range of issues. In this respect, high level strategic cooperation council mechanisms that have been established with Kyrgyzstan and the Cooperation Council with Tajikistan provide a useful base for the further relations between Central Asian republics and 
Turkey. Nonetheless, Turkey's interest in Central Asia is mainly economic partnership. According to Kutlay and Dogan (2011)

The rise in trade and investment flows with Central Asia and Turkey's belated willingness to revive the old "Silk Road" trade routes mean that Ankara has been making real progress in the mutually beneficial economic partnerships Turkish firms have established in the five republics of Central Asia. But this does not mean in any sense that Turkey is engaging with its "Eastern" Central Asian neighbors at the expense of the "rest". Quite the contrary: Turkey aims to position itself as a "central country" at the intersection of a geographically strategic region, a key Eurasian power within the EU. Hence, Ankara acknowledges that the same democratization and Europeanization processes that have helped Turkey to achieve its remarkable economic and political developments of the past 10 years helped create spill-over commercial and diplomatic effects into its relations with its Central Asian neighbors. Finally, Turkey has brought economic and political stability to that crucial part of the world which constitutes a vital link between Western Europe and Asia. What Turkey expects from its European friends and allies is simply to be recognized as an equal, equally European, partner as it strives to further the security and welfare of the region."

Turkey has renewed its interest in the West Balkans as a part of Turkey's efforts to enhance "strategic depth" doctrine of Davutoglu and AKP's tendencies of Neo-Ottomanism. During his official visit to Sarajevo in 2009 Turkish Foreign Minister Davutoglu had explicitly linked Turkey's foreign policy to the legacy of the Ottoman Empire stating that "the Ottoman centuries of the Balkans were success story. Now we have to reinvent this... Turkey is back." Ever since then Ankara has been trying to regain lost influence in the region, by showing impressive diplomatic and economic activism. There are three complementary goals of the Turkey's recent diplomatic activities in the Balkans: to strengthen Turkeys good relations with its traditional partners in the region; to improve the relations with the countries Turkey has had problematic relations before; and to play the role of the mediator and lead the multilateral initiatives to improve regional stability. 
Examining the number of official visits Turkish Foreign Minister had made to Bosnia-Herzegovina one can easily notice that he has been flying a lot to Bosnia. Turkey has always been in support of Bosnian territorial integrity and stability. At the same time Turkey has been vocal advocate of Bosnia's membership to NATO's Membership Action Plan (MAP). Then, Turkish relations with the Former Yugoslavian Republic of Macedonia (FYROM) are best understood from the statement of Ahmet Davutoglu during one of his visits to Macedonia where he states "The citizens of the Republic of Macedonia, wherever they are in the world, can, if they need help, call the embassies of Turkey. They will get help as they are Turkish citizens"

(Duridanski, 2011). Then, Turkey has been great supporter of Skopje's Euro-Atlantic integration process and has encouraged NATO to invite FYROM even before name dispute with Greece was settled down. Turkey also took the initiative to improve its bilateral relations with Serbia. The Turkish President Abdullah Gul paid an official visit to Belgrade in 2009. Prior to his visit, 23 years Turkish head of states have been avoiding Serbia. In the joint statement both presidents declared that relations between Turkey and Serbia have never been better. Furthermore, Ankara has been thought to have played a great role in encouraging Serbian parliament to adopt the Declaration of Srebrenica on 30 of March 2010. Serbia officially apologized for the role in the Srebrenica genocide 1995. Turkey has also played a great part in the calming down the situation in Serbia's Sandžak region by opposing demands for autonomy from Serbia by some local Muslim communities. Turkey has urged three fractions of Bosniaks communities to settle down their differences. For this purpose, Turkey has opened a Turkish Cultural Center in Novi Pazar.

In the wake of political turmoil in Serbia regarding self-proclaimed independence of Kosovo Turkish Prime Minister Recep Tayyip Erdoğan expressed his country's willingness to mediate in the bilateral-talks between Belgrade and Prishtina in November 2010. Nonetheless, Ankara's most significant mediation success was the Istanbul Declaration on Peace and Stability in the Balkans signed by Serbia, Croatia, and Bosnia-Herzegovina on April 24, 2010. With the three Balkan countries pledging to improve cooperation and work toward EU integration, Ankara appeared as a key player in the stability of Southeastern Europe. 


\section{References}

Bal, Idris. 2000. Turkey's Relations with the West and the Turkic Republics: The Rise and Fall of the " Turkish Model." Aldershot, England: Ashgate

Christensen, Mette Buskjaer. 2009. EU-Turkey relations and the functioning of the EU. Danish Institute for International Studies.

Cook, Steven A. 2010. “Weakening of Turkey`s Military." Expert Brief. The Council of Foreign Relations.

Davutoglu Ahmet. 1994. Alternative Paradigms: Impact of Islamic and Weltanschauungs on Political Theory. Lanham: University Press of America.

Davutoglu, Ahmet. 2001. Strategic Depth. Istanbul: Kure Yayinlari.

Davutoglu, Ahmet. 2008. "Turkey's Foreign Policy Vision: An Assessment of 2007." Insight Turkey, Vol.10, No.1.

Duridanski, Darko. 2011. "Macedonia-Turkey: The Ties that Bind." Balkan Insight.

Evin, Ahmet et. al. 2010. Transatlantic Report 'Getting to Zero.' Washington DC: Transatlantic Academy.

Jenkins, Gereth. 2001. Context and Circumstance: The Turkish Military and Politics. Oxford: Oxford University Press.

Karaosmanoglu, Ali. 2000. "The evolution of the National Security Culture and the Military in Turkey." Journal of International Affairs.

Kuniholm, Bruce. 1980. The Origins of the Cold War in the Near East. Princeton: University Press.

Kutlay, Mustafa and Salih Dogan. 2011. Turkey and Central Asia: Modern Economic Lincages along the "Silk Road"

Murinson, Alexander. 2006. "The Strategic Depth Doctrine of Turkish Foreign Policy." Middle Eastern Studies, Volume 42, Issue 6.

Rabasa, Angel, et. al. 2007. Building Moderate Muslim Network. California: RAND Cooperation.

Onis, Ziya and Suhnaz Yilmaz. 2009. "Between Europeanization and Euro-Asianism: Foreign Policy Activism in Turkey during the AKP Era." Turkish Studies, Vol.10, No.1

Turan, Ilter. 2010. "Turkish Foreign Policy: Challenges to Turkey's Western Calling."

Turk Istiklal Harbi Mandros Mutarekesi ve Tatbikati. 1992. Ankara: Genel Kurmay Basimevi. 